\title{
The IIIrd International Innovative Mining Symposium at T.F. Gorbachev Kuzbass State Technical University as a Step to Closer Cooperation of Science, Education and Business in the Mining Region
}

\author{
Andrey Krechetov ${ }^{1, *}$ \\ ${ }^{1}$ T.F. Gorbachev Kuzbass State Technical University, Rector, 650000, 28 Vesennyaya St., Kemerovo, \\ Russia
}

\begin{abstract}
For the third time T.F. Gorbachev Kuzbass State Technical University is holding an event important for Russian mining science and education, expanding the boundaries of interaction between scientists and practice experts, opening up new opportunities for joint discussion of the most urgent problems of mineral resources sector development in Russia and other countries. The vector of discussions of the Third Mining Symposium is aimed at solving the pressing problem of extracting sector of economy and raw material clusters development - ensuring environmental and industrial safety. Today, this largely determines the benchmarks of the innovative development of mining and deep processing of minerals, recycling of mining waste, import substitution of modern equipment for enterprises of the mineral resources sector. Currently, issues of environmental and industrial safety go far beyond the regulatory framework, turning into a comprehensive engineering, educational and social-and-economic discourse, forming a new agenda and culture of interaction between science and production, a new league of representatives of the international community of technical universities.
\end{abstract}

\section{Introduction}

The Third International Innovative Mining Symposium (successfully held October 03-05, 2018) became a place for discussing environmental and industrial safety issues in the solid mineral deposits mining. It brought together universities and authorities, representatives of Russian and foreign companies engaged in the extraction and processing of mineral raw materials, recycling of wastes, mining equipment production and service.

More than 400 scientists and teachers, enterprises representatives, members of business community and government bodies, students and post-graduates became the guests of Opening and Plenary Session at the IIIrd Symposium.

\footnotetext{
*Corresponding author: kuzstu@kuzstu.ru
} 


\section{Materials and Methods}

The participation of more than 400 representatives in the Symposium made possible not only to expand the network of business, scientific, educational and cultural ties, but also exchange experience in advanced processing of solid mineral deposits, preserving the biodiversity of mining regions and creating a favorable environment for the residents of coal mining localities.

Researchers, engineers and managers of Russian and foreign companies of solid minerals mining and processing, equipment manufacturing and servicing, took part in the round tables "Modern Coal Processing Technologies", "Economic and Social Development of Mining Regions", in Sections: "Environmental and Industrial Safety of Coal Mining", "Geotechnology: Underground, Surface, Construction", "Mining Machines and Equipment", "Electrical Equipment and Automation in Mining" (Figure 1).
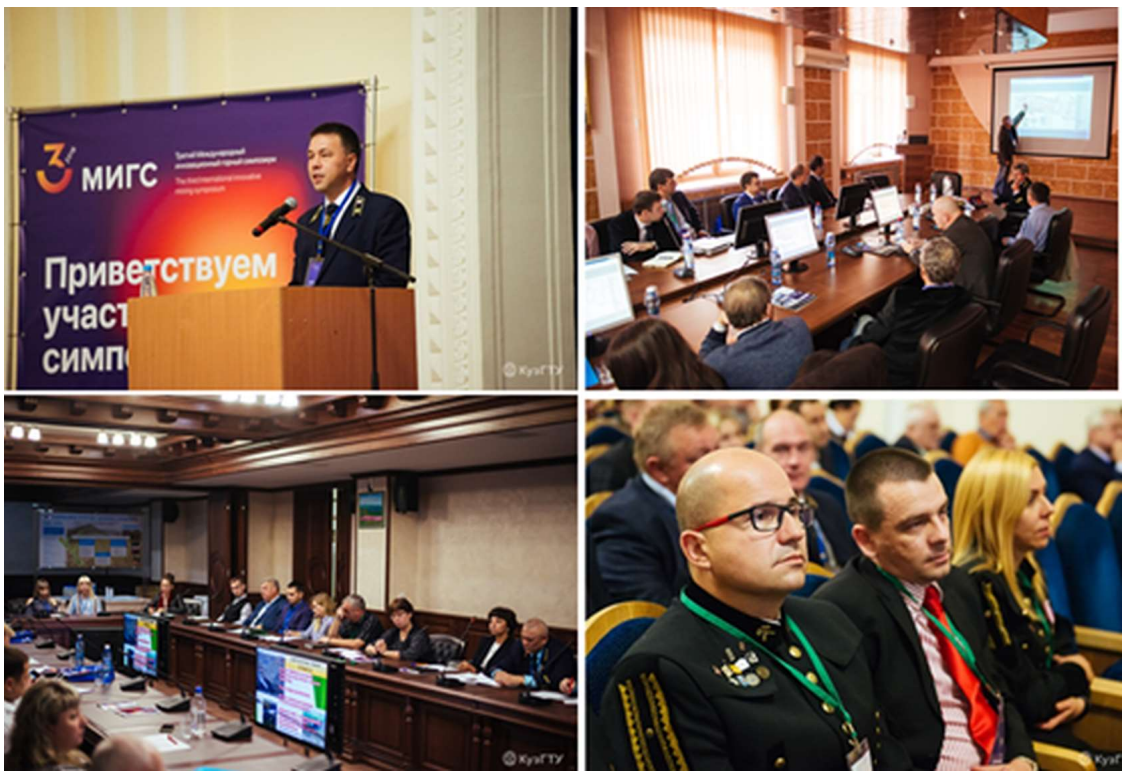

Fig. 1. The work of Symposium.

\section{Results and Discussion}

\subsection{The Plenary Session}

The Plenary Session of the Third International Innovative Mining Symposium began with a welcoming speech from Rector of T.F. Gorbachev Kuzbass Technical University Andrey A. Krechetov and honored guests:

1. Vladimir I. Klishin, Director of the Coal Institute of the Federal Coal and Coal Chemistry Research Center, Siberian Branch of Russian Academy of Science.

2. Izabela Kotarska, Chief Specialist of Environmental Protection and Processing Department of R\&D Center, KGHM CUPRUM Ltd. (Poland), with the report "Mining Waste in the Circular Economy - Idea Versus Reality". 
3. Andrey O. Brizhak, Head of the Department of Coal Mining and Processing Enterprises Safety, Coal Industry Department of Kemerovo Region Administration, with the report: "Key Parameters of the Kuzbass Coal Industry Development Strategy until 2035".

4. Sergey M. Nikitenko, DSc in Economics, Leading Researcher, Federal Coal and Coal Chemistry Research Center, Siberian Branch of Russian Academy of Science, Director of Association of Machine Producers of Kuzbass, with the report "Innovations as a Basis for the Project Interaction of Science, Business and Government in Forming Points of Economic Growth".

5. Andrey I. Kalachev, General Director of PCV Ltd., Leader of the Phoenix Consortium, expert of the Committee on Energy of the State Duma of the Russian Federation, with the report: "Legislative Initiatives on Greening Coal Generation in the Russian Federation".

6. Martin Bunzel, Business Development Manager - Russia, Schauenburg Maschinenund Anlagen-Bau GmbH (Germany) with the report: "Possibilities of Wet-Mechanical Treatment of Ashes from Coal-Fired Power Plants".

\subsection{The Round Tables}

A) Round Table "Modern Technologies of Coal Procession".

Organizers: T.F. Gorbachev Kuzbass State Technical University, JSC "Institute Giprougol", MBE Coal \& Minerals Technology GmbH (Germany), Feluwa Pumpen GmbH (Germany). The meeting was attended by over 50 representatives $-\mathrm{CEO}$ of the processing plants, design and research institutes of Russia and foreign companies from Slovakia, Germany and Kazakhstan.

The opening speech of P. Hennig, the Head of MBE Coal \& Minerals Technology $\mathrm{GmbH}$, revealed the results of 15 years fruitful cooperation with the Department of Mineral Processing of T.F. Gorbachev Kuzbass State Technical University.

Presentations were made by:

- Lutz Markworth: "Review of Project for Successful Implementation of the First Flotation Line Using Pneuflot Flotation Machine at Kuzbass Coal Preparation Plants".

- Sazykin, G.P., Syvorotkin, K.N. (JSC "Institute Giprougol"): "Design and Construction of Processing Plants in the City (by Example of Kuzbass Coal Preparation Plant of "Mine Number 12")."

- Rassmann T. "The Implementation and Operation of Two-Hose Membrane Pump MULTISAFE".

- Udovitsky V.I., Fairushin Sh.A., Valiullov N.R. "On the Training of Specialists in Mineral Processing at T.F. Gorbachev Kuzbass State Technical University."

At the Round Table guests - the directors, chief engineers of the processing plants and design institutes, expressed an unanimous demand for increasing the number of students future mineral processing engineers.

B) Round Table "Economic and Social Development of Mining Regions".

Moderators of the Round Table were: Director of the Institute of Economics and Management of KuzGTU Natalya V. Kudrevatykh, Professor Sergey V. Bereznev, DSc in Economics.

At the Round Table during the discussion of the issues of social and economic development of mineral and raw materials clusters, the following problems were presented in the reports: A New Industry in the Framework of Social and Economic Development Strategy of Kemerovo Region Until 2035; World System Analysis of the Role of Kuzbass in the New Development Strategy of Russian Federation; The Study of Main Indicators of the Local Environmental and Economic System: "Industrial Enterprise - Environment"; Environmental Management Issues as the Limiting Factor in the Development of Coal Mining 
Region; The Possibilities of Improving the Competitiveness of Agricultural and Industrial Complex of Mineral Resource Cluster.

\subsection{The Sections}

1. "Environmental and Industrial Safety of Coal Mining".

Moderators: Yury A. Manakov, DSc in. Biology, Laboratory Head of Federal Coal and Coal Chemistry Research Center, Siberian Branch of Russian Academy of Science; Sergey I. Protasov, PhD., Director of Innovation Firm "KUZBASS-NIIOGR".

The section was attended by 47 experts who represented 15 scientific and educational institutions from 5 cities of Siberian Federal District, Moscow and abroad. Along with scientists, the representatives of Kuzbass coal companies and enterprises, as well as research and production firms, took part in the section.

In this Section eighteen reports were made in the following areas: Legislative and Scientific Principles of Subsoil Use; Sustainable Development of Coal Mining Regions; Preservation of Biodiversity During Coal Mining; Best Available Technologies and Environmental Policy of Coal Companies; Safety and Labor Protection in Underground and Open-cast Coal Mining, Coal Enrichment, as Well as Reducing the Impact of Coal Industry Technological Processes on the Environment, in particular by Justifying Seismic Safety Parameters of Mass Explosions and Applying New Blasting Technologies.

The participants of the Section noted that the extraction of mineral resources is the most important sector of the Russian economy, which is dynamically developing with the growth of productivity and technical support of mining operations. Moreover, for the comprehensive development of mining regions, the main issue is not only a new technological and economic breakthrough, but also the preservation of friendly environment for the residents of Kuzbass.

2. "Mining Machines and Equipment", "Electrical Equipment and Automation in Mining".

Moderators: Prof. Alexey A. Khoreshok, DSc., Director of Mining Institute of KuzSTU; Sergey G. Mukhortikov, PhD, Deputy Chief Mechanic of SUEK-Kuzbass JSC.

Among the Section participants were the representatives of the Innovation Company Center of Hydraulics DOH (Poland), Ural State Mining University, Perm National Research Polytechnic University, Belaz-24 Ltd, Becker Mining Systems RUS Ltd, KuSTU, Yurga Institute of Technology of National Research Tomsk Polytechnic University.

The topics of reports included the following: The Efficiency of Executive Elements of the Hydraulic Systems of Powered Roof Supports; Automation of Air Preparation at Mines; The Influence of Number and Area of Contact of the Transmission Elements of the Traction Force on the Stress-strain State of Geohod Junction Section; Development of A System for Controlling Interconnected Voltages to Improve the Energy Efficiency of Coal Mines, Warning A Dangerous Collision at Mine; Prospects for the Development of Belaz, the Issues of Service Engineers Adaptation and Competencies Development; the Method of Conformal Mapping Theory of Circular Grids of Mine Turbomachinery.

3. "Geotechnology: Underground, Surface, Construction".

The Section's Moderators were: Prof. Alexey A. Renev, DSc, Head of the Department of Mineral Resources Development, T.F. Gorbachev Kuzbass State Technical University, Prof. Vladimir V. Pershin, DSc, Head of the Department of Underground Structures and Mines, KuzSTU.

The Section united reports on the following topics: The Impact of Coal Mining on Conditions of Coal Headings and Pillars During Thick Seam Mining; Ensuring Industrial and Environmental Safety During Coal Mining; Proportionality and Cyclical Development of the Working Area of Open Pit; Improving the New Lining of Headwork of Inclined Shafts of Coal Mines; the Substantiation of Parameters of Coal Mining With the Use Of Mecha- 
nized Roof Support under Board-and-Pillar Work System, Geomechanical Substantiation of Parameters of Maintaining the Wide Face-End of Mine Workings in The Area of Longwall Influence; the Assessment of Emergencies at Vertical Shafts Deepening under Servicing Hoist.

\section{The Resolution}

The Resolution of the IIIrd International Innovative Mining Symposium (Adopted by the participants of the Symposium on October 05, 2018) proclaimed the following.

The Third International Innovative Mining Symposium was held at T.F. Gorbachev Kuzbass State Technical University, Kemerovo, Russian Federation, October 03-05, 2018. The number of participants was 516 (of which 193 were virtual participants).

The international team of guests and participants included representatives of universities, innovation and industrial companies from Germany, Slovakia, Poland, Ukraine. Together with Russian guests and participants from Moscow and St. Petersburg, Tver, Kemerovo, Novosibirsk, Tomsk regions, Perm and Krasnoyarsk territories, they heard and discussed 63 reports on topics of the Plenary Session, Round Tables, Sections and Panel Discussions.

The reports presented at the Symposium highlighted the need for systematic study and comprehensive development of the legislative and scientific foundations of subsoil use, improvement of environmental and social policies of coal companies, solving environmental and labor safety problems during mineral resources extraction and processing, innovative modernization of mineral resource extracting and processing enterprises, waste disposal, training of highly skilled personnel.

The Symposium participants agreed that this set of directions of scientific discussions is associated with the task of national importance - the implementation of the provisions of the Long-Term Social and Economic Development Forecast of the Russian Federation for the period up to 2030, particularly in terms of Section 8 "Environmental Protection. The Development of Resource Potential of Economy."

In this regard, following the results of Round Tables, Plenary Session, Sections and discussions, the Plenary Committee of the Third Symposium recommends the Ministry of Natural Resources and Environment of Russian Federation to attract companies and enterprises to solving the problems of biodiversity conservation in coal regions:

1. To provide information about conditions and characteristics of the environment in the description of subsoil plots in the State Register of Mining Operations based on data from the Public Councils under the executive authorities of the regions, experts from regional branches of the Public Front and Public Chambers, as well as specialized organizations.

2. To develop and implement measures to encourage subsoil users to include biodiversity conservation and restoration in their activities.

3. To include experts in biodiversity conservation as the members of commissions for the Government Environmental Expert Testimony of projects.

4. To exclude areas of unique and unrecoverable ecosystems from subsoil use and environmental management. To develop a mechanism to prevent the destruction of unique biodiversity in licensed mining areas.

5. To implement the Resolution of the V-th All-Russian Environmental Congress, initiate the process of creation the National Platform "Business and Biodiversity" on the basis of the Ministry of Natural Resources and Environment of Russian Federation, developed in the framework of the UNDP-GEF / Ministry of Natural Resources and Environment of Russian Federation / Project "Objectives of Biodiversity Conservation in the Policy and Development Programs of the Power Producing Sector of Russia". 
To implement the provisions of the Development Strategy of Kemerovo Region until 2035, it was recommended to the Administration of Kemerovo Region to work out:

1. Kemerovo Region Coal Industry Development Program in order to streamline and coordinate the volumes and locations of coal mining with the development of a plan for restoration of disturbed territories and control of its implementation.

2. The Strategy of Biodiversity Conservation and Specially Protected Natural Areas Development for Kemerovo region.

3. The strategic environmental assessment of the Program of Social and Economic Development of Kemerovo Region, taking into account the social structure and biological value of the territories.

In the introduction period of the best available technologies and improved requirements as a part of environmental regulation, the heads of coal companies, mines, coal preparation plants of Kuzbass, as well as design institutes are offered the following:

1. To pay attention not only to the economic efficiency of advanced scientific research results implementation, but above all to their ability to ensure industrial safety and reduce the environmental damage caused by mining.

2. To develop corporate programs for modernization of production based on the best available technologies under ITS 16-2016 "Mining industry. Common processes and methods".

3. To develop corporate strategies and standards in accordance with the hierarchy of measures to reduce negative impacts on biodiversity in the chain: "Prevent - Reduce - Restore - Compensate".

4. To increase the disclosure of mining companies through corporate social reporting and posting the project documents which have passed the state approval in terms of Environmental Impact Assessment (EIAs) on official websites.

5. To develop the environmental management of companies, improve the professional level of employees, provide with extra skilled specialists to perform new tasks in terms of the company's environmental responsibility and public reporting.

6. To apply digital technologies and Geo Information Systems (GISs) to improve industrial environmental monitoring.

7. To participate in drafting the regional plans for specially protected natural territories development.

8. To draw the attention of academic and industry research institutes, universities and design organizations to the need for a radical revision of mining technological processes, taking into account the restricting of modern legislative requirements in the field of industrial safety, protection of subsoil and environment.

9. To work out the issues of foundation of coal technological complexes (clusters) with continuous extraction and enrichment of coal, as well as the recycling of coal preparation and burning waste.

To ensure a high level of personnel potential of mining industry specialists, it was recommended to the universities of Kemerovo region:

1. To include in curriculum the results of new research and engineering developments in the field of technology, mechanization and automation of coal mining and enrichment, the revitalization of disturbed lands, ensuring industrial safety and reducing negative impact on environment.

2. To consider the importance of high-quality training of mining engineers in industrial safety, conduct regular certification of teachers of core disciplines for students of mining specializations in general issues of industrial safety, in accordance with the requirements of ROSTECHNADZOR of 29.01.2007 No 37 "On the Order of Training and Certification of Employees of Organizations Supervised by the Federal Service for Environmental, Technological and Nuclear Supervision". 
3. To attract students and post-graduates to the conferences and exhibitions devoted to the development and increase of economic efficiency of introducing new research results that simultaneously ensure the industrial and environmental safety of coal industry enterprises, increasing their competitiveness in the global energy market.

\section{Conclusion}

The Fourth International Innovative Mining Symposium is planned on October 2019, as the regular high-ranking scientific event, a discussion platform for scientists, expert practitioners, active innovators, members of the Russian and international mining community, as well as a place of acquaintance with the utmost culture of unique mining region - Kuzbass.

The international community of mining engineers, research scientists in the fields of mining and solid minerals processing, industrial ecology, mining machinery and equipment, sustainable social and economic development of mining clusters, takes a keen interest in discussing important issues of innovative development of mineral resources sector.

Today it is obvious that the future of mining is impossible without taking into account demanding environmental requirements for solid minerals mining and processing, without revitalizing the areas disturbed by mining, without introducing Industry 4.0 technologies into the production of mining machinery and equipment, especially safety equipment, without forming programs for integrated innovative and social and economic development of mining clusters.

The necessity to unite the efforts of science and education representatives, stakeholders is caused by the complexity and interdependence of discussed industrial, environmental, organizational and economic problems that enterprises and companies of mineral resource sector, administrations of mining regions face within the transition to the new technological layer, within expanding the share of the Russian Federation in the world energy market.

At the IVth International Innovative Mining Symposium the range of topics will follow the debated problems of geotechnology and mineral processing development, coal-fired power industry in the mining regions, the introduction of smart systems for managing mining machines and equipment, ensuring industrial and environmental safety, reclamation and post-mining, social and economic development, training of engineers with the competences of global level.

The main working areas of the Fourth Symposium:

1. Innovative technologies of mining, transportation, utilization, processing and recycling of mineral raw materials.

2. New types of mining equipment, innovations in power industry, mechatronics and automation of technological processes.

3. Environmental issues of mineral resources extracting clusters and their solutions.

4. Social and economic development of mining and old industrial areas.

The program of the Fourth Symposium includes: the Plenary Session, the work of Panel Discussions, Thematic Sections and Round Tables, presentations and the adoption of the final Resolution.

The Organizing Committee and scientific editors express their gratitude to the publishing house EDP Sciences (France) and the scientific serial E3S Web of Conferences as a part of EDP Sciences for their prompt assistance in publishing the materials of the I, II and III Innovative Mining Symposiums and indexing in the international scientific citation database Scopus (Elsevier). 


\section{References}

1. A. Krechetov, E3S Web Conf., 41, 00001 (2018)

2. A. A Krechetov, A. A. Khoreshok, V. Yu. Blumenstein, E3S Web Conf., 21, 0001 (2017)

3. M. Cehlár, J. Janočko, S. Anyona, M. Tyulenev, S. Zhironkin, E3S Web Conf., 21, 0002 (2017) 